\title{
PROBLEM OF IMPROVEMENT THE QUALITY OF PRODUCTS WITH USE INDUSTRIAL WASTE
}

\begin{abstract}
Steel is dominating construction materials applied in different branch of economies. How the studies concerning perspective development are passing all construction materials position of steel still long not changing. Very steel is friendly to the environment, but her waste (scrap) it is possible to process again into the functional product. The steel production is very much material and energy intensive. Over half of materials and raw materials entered into integrated manufacturing processes of steel (large stove-converter) is creating by products on the exit, waste. The article constitutes the inspection of raw material potential once possibilities using waste.
\end{abstract}

Keywords: process, product, waste

\section{Introduction}

The amount slag accompanying the steel production on the electric steelworks constitutes the minimum of $10 \%$ in relationship up to the produced number stood. Marking it, that in Poland, where is produced in final years to $9 \mathrm{Mg}$ of steel for the year (from what to $5 \mathrm{Mg}$ in the process integrated but up to $4 \mathrm{Mg}$ in the electric process). Physicochemical properties of slagss much are running away from properties of raw materials applied for producing them.

In Table 1 sizes were given to produced steel "strict" in Europe in 2014 (CHOJECKI A., TELEJKO I. 2014).

Table 1. Size of the steel production "strict" in Europe in 2014

\begin{tabular}{|l|l|}
\hline Country & Production in 2014 in the Mg \\
\hline Austria & 7422 \\
\hline Belgium & 7385 \\
\hline Bulgaria & 640 \\
\hline Czech & 5072 \\
\hline Finland & 3758 \\
\hline France & 15609 \\
\hline Germany & 42667 \\
\hline
\end{tabular}

\footnotetext{
${ }^{1}$ dr inż. Jacek Sitko, Silesian Technical University, jsitko@ polsl.pl

${ }^{2}$ dr hab. inż. Witold Biały, prof. Pol. Śl., Silesian Technical University, wbialy@ polsl.pl 


\begin{tabular}{|l|l|}
\hline Grece & 1256 \\
\hline Hungary & 1543 \\
\hline Italy & 27229 \\
\hline Luksembourg & 2230 \\
\hline nederlands & 6876 \\
\hline Poland & 8369 \\
\hline Romania & 3780 \\
\hline Spain & 13623 \\
\hline Sweden & 4326 \\
\hline Great Britain & 9755 \\
\hline
\end{tabular}

Source: CHOJECKI A., TELEJKO I. 2014

\section{Technical description enterprise}

BOL REC is altering in stoves recycled zinc raw materials so as metallurgical dusts and slimes containing toxic ingredients (lead, chlorine, fluorine and aka) producing zinc oxides being used to receive the tip off the highest kinds.

The enterprise is equipped with six rotary furnaces for the $\mathrm{m} 40 \mathrm{~m}$, and diameter 3 long, has a production capacity of steel making dusts c 120000 t/r. (Fig. 1).

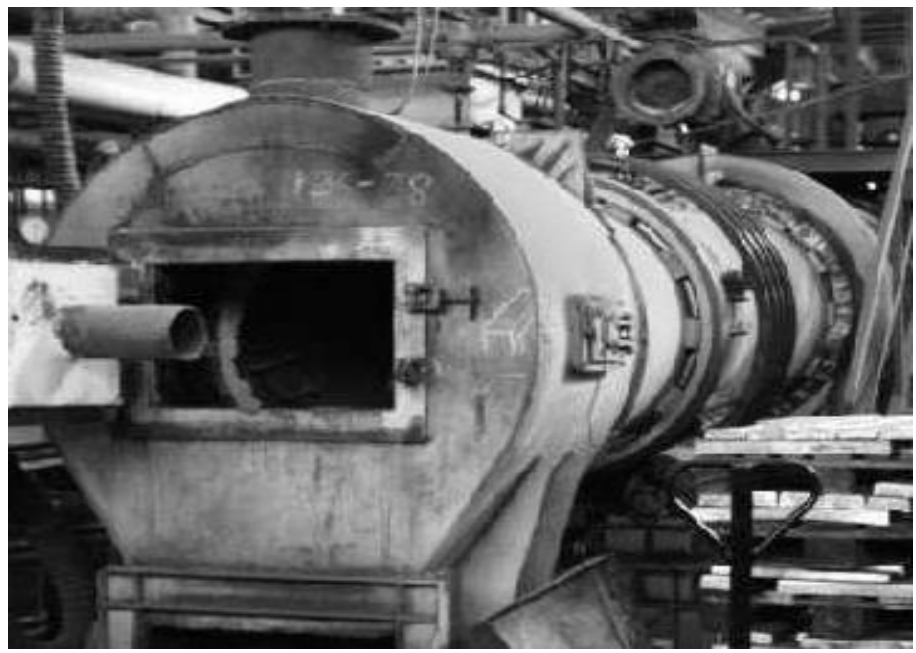

Source: own study on IMN

Fig. 1. Smelting stove, general view. 
On account of great mass of obtained cinders, constituting $65 \%$ in taking the zinciferous batch back to dry mass to the stove, one should treat cinder not as waste but as by products.

Conditions of litigating knocked down should be established so that received slag tracks contain as fewest pollutants (mainly so as $\mathrm{Zn}$ and $\mathrm{Pb}$ ) which are hampering developing slags.

Zinc is particularly undesirable in processes of metallurgy iron on account of destructiveness for fireproof laying out blast furnace.

They in Poland assume that the content of zinc in batch cannot cross $0.5 \mathrm{~kg}$ to one ton of material, and in the west $0.2 \mathrm{~kg}$ to the ton of the material. In the blast furnace, zinc causes the formation of characteristic accretions on wall of stove which periodically are breaking away what is leading for fast consuming laying blast furnace out. Thickening slag and the increase in his viscosity are taking place what leading triggers is hampering.

They observed, that inside the blast furnace, the tip off is circulating; stays of it in the stove more than it results from the amount included in the batch. This circulation consists in the reduction in the zinc oxide in bottom ends of the blast furnace, for raising pairs of zinc up, and then on the condensation pairs on pieces the batch and in wall. Condensing pairs of zinc at times fire resistant materials wall of blast furnace work particularly oppressively on structure of material wall.

\section{Characteristics of inspected metallurgical slags tracks}

Slag are a byproducts of metallurgic processes and depending on type process, chemical composition, the kind of fire resistant material used for the structure of stove differ in chemical composition, mineralogical. Metallurgical cinders are more and more often the focus of attention under the angle possibilities developing them, especially as materials applied in production of high quality casts after refining, elements of building materials, elements abradant for surface treatment regenerated machinery parts and (in case of low processed aggregates) materials mines and applications in road (Mole J., MojźiszeK J. 2007; KRUPKA D., SitKo J., OCHAB B. 2006). Research works concerning developing slags are being conducted both of current smelting production as well as slags stored up on stockpiles.

Properties of steel making slag

Steel making slags is characterized by a very high resistance to mechanical factors of different kind:

Pressure steel-making slags isn't losing its shape and isn't cracking under the burden of even great weights. Moreover a fact that he isn't settling in land is stamping 
it the base coat of slags isn't lowering its level and isn't deteriorating, it is possible to put next layers practically at once. Everything is bringing it behind itself a lot to the benefit - roads from steel making slag can come into existence in a very short time and don't require the too costly conservation in addition.

The high humidity and the temperature slag is characterized by a very low water absorption and a great resistance to freezing. It is particularly essential in period jesienno winter, when falls are frequent, and temperatures are falling below zero. Thanks to its properties steel making slag less is exposed to erosion caused by freezing of water.

Slags from the ferrous metallurgy

In the ferrous metallurgy most widely two types of slags are spread: blast furnace slags incurred at the production of slag (steel making) incurred in course of smelting stood.

Model yard of blast furnace slag and converter from mill for them. presented in Table 2.

Table 2. Chemical composition of slags

\begin{tabular}{|c|c|c|}
\hline \multirow{2}{*}{$\%$} & \multicolumn{2}{|c|}{ Kind of slag } \\
\cline { 2 - 3 } & Blast furnace & Converter \\
\hline $\mathbf{C a O}$ & 43 & 43 \\
$\mathbf{M g O}$ & 7 & 4 \\
$\mathbf{S i O}_{2}$ & 36 & 16 \\
$\mathbf{A l}_{\mathbf{2}} \mathbf{O}_{3}$ & 7 & 3 \\
$\mathbf{M n}_{\mathbf{~}}$ & 1,5 & 4,5 \\
$\mathbf{F e}_{\mathbf{o g}}$ & 5 & 21 \\
$\mathbf{S}_{\mathbf{g g}}$ & $<1$ & 0,2 \\
$\mathbf{W i l g o c ́}^{\left(\mathbf{H}_{2} \mathbf{O}\right)}$ & 5 & 3 \\
\hline
\end{tabular}

Source: KAZABAER L.A., KOZLOV P.A. 2005

Blast furnace slag

Before, after the completion of smelting of the salad in the blast furnace, cinder in the liquid state, was lowered into the vat and taken away to slag heaps, where after pouring out flowed down hillsides and was subject to chilling in air conditions (Fig. 2). 


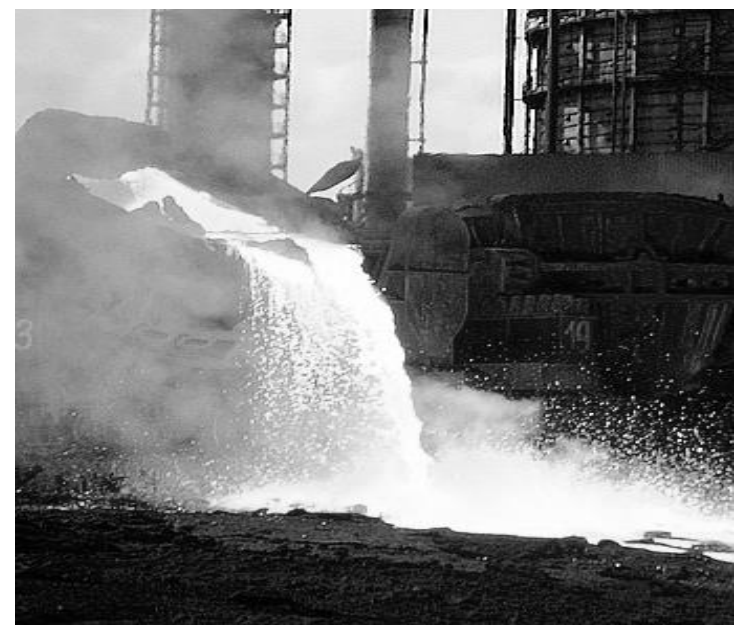

Source: own study

Fig. 2. Process of pouring slag out.

In the course of cooling he is reaching to the crystallization of row minerals, mainly so as:

- magnesium silicates and of calcium,

- aluminosilicates of magnesium and calcium,

- iron oxides, of manganese and magnesium.

The blast furnace slag can also quickly be chilled with water; then he is undergoing the granulation and a porous structure of hardened material is formed.

During the process of fast controlled it is possible to produce the cooling foamed cinder which spongy material applied for the production of light aggregate forms.

\section{Converter slag}

Converter slag is a product of steel. Liquid slag from the converter is being granulated to the purpose of slow solidifying, in course of which hot speedway mass they are crystallizing silicates two and three calcium, calcium ferrite, wustyt and pollutants coming from the batch.

In the ferrous metallurgy we can single major groups of waste out (TAJCHMAN F., TORACH B. 2004.):

- blast furnace slag and steel-making

- scale

- scrap metal from the rolling mill, from the steelworks and from the blast furnace department 
- dusts and slimes.

Mass of slags is greatest and at present, mass of slags in the metallurgy is an about 300 $\mathrm{kg}$ to the ton of the product, and in individual milles fluctuates from the about $180 \mathrm{~kg} / \mathrm{t}$ to over $400 \mathrm{~kg} / \mathrm{t}$. In Poland to $1980 \mathrm{r}$. this share still amounted to about $700 \mathrm{~kg} / \mathrm{t}$, and at present is hesitating between 300 and $400 \mathrm{~kg} / \mathrm{t}$. The blast furnace slag is alloy (in turn reducing) $\mathrm{CaO}, \mathrm{SiO}_{2}, \mathrm{MgO}$ and $\mathrm{Al}_{2} \mathrm{O}_{3}$ - the proportion of these two last elements is changing in individual milles, the $\mathrm{MgO}$ content can be bigger or smaller than the $\mathrm{Al}_{2} \mathrm{O}_{3}$ content. These four ingredients are providing about $95 \%$ of mass of cinder. Model chemical composition in with including the $\mathrm{Zn}-\mathrm{Pb}$ metallurgy is showing Table 3.

Table 3. Chemical compositions

\begin{tabular}{|c|c|c|c|c|}
\hline \multirow{2}{*}{} & \multicolumn{4}{|c|}{ Content of elements, \% of mass. } \\
\cline { 2 - 5 } & \multicolumn{2}{|c|}{ Steel } & \multicolumn{2}{c|}{ Zn-Pb } \\
\cline { 2 - 5 } Al & $0,36-8,37$ & 2,92 & $6,12-8,12$ & 6,82 \\
\hline $\mathbf{A s}$ & - & - & $0,20-0,79$ & - \\
\hline $\mathbf{B i}$ & - & - & $0,01-0,02$ & - \\
\hline $\mathbf{B r}$ & - & - & 0,01 & - \\
\hline $\mathbf{C}$ & - & - & $0,16-17,25$ & - \\
\hline $\mathbf{C a}$ & $0,89-13,30$ & 6,34 & 4,19 & - \\
\hline $\mathbf{C d}$ & - & - & $0,03-0,22$ & - \\
\hline $\mathbf{C u}$ & - & - & $0,01-0,03$ & 0,02 \\
\hline $\mathbf{F e}$ & $5,98-23,33$ & 16,01 & $2,26-3,01$ & 2,60 \\
\hline $\mathbf{K}$ & - & - & $2,30-7,27$ & 3,73 \\
\hline $\mathbf{M g}$ & $0,23-5,79$ & 2,90 & 0,15 & - \\
\hline $\mathbf{M n}$ & 2,40 & - & $0,75-2,03$ & 1,30 \\
\hline $\mathbf{N a}$ & - & - & $2,74-5,28$ & 3,72 \\
\hline $\mathbf{N i}$ & - & - & $0,01-0,04$ & 0,02 \\
\hline $\mathbf{O}$ & $54,04-69,99$ & 64,79 & $41,56-46,60$ & 44,47 \\
\hline $\mathbf{P}$ & 1,16 & - & $1,20-3,01$ & 1,93 \\
\hline $\mathbf{P b}$ & - & - & $0,03-0,22$ & 0,10 \\
\hline
\end{tabular}




\begin{tabular}{|c|c|c|c|c|}
\hline $\mathbf{S}$ & $0,20-0,65$ & 0,42 & $2,45-4,68$ & 3,67 \\
\hline $\mathbf{S e}$ & - & - & 0,53 & - \\
\hline $\mathbf{S i}$ & $3,05-9,65$ & 5,68 & $21,84-28,00$ & 25,18 \\
\hline
\end{tabular}

Source: own study

\section{Summary}

In the article they checked the raw material potential and analysis of possibility developing metallurgical slags from the ferrous metallurgy and non ferrous metals, chemical, mineralogical characteristics in steel making dusts which is embracing:

- gradual grinding and the magnetic separation treatment of slags in the destination of acquiring two fractions - magnetic, containing metals and nonmagnetic including the possibility of developing cinders in metallurgical process as the element for refining of alloys metals iron and non ferrous metals (among others stell, bronzes).

- in production metal high tough casts and the possibility of applying slags as the element ceramic clinker at the manufacture of cement in the construction,

- using the nonmagnetic fraction slags at abrasive works,

- examining the possibility of applying speedway racings for obtaining ferric pigments.

Described analysis of selected aspects developing the smelter waste requires further deepened examinations.

\section{Bibliography}

1. ChOJECKI A., TelejKo I. 2014. Odlewnictwo staliwa. Kraków: Wyd. Naukowe Akapit.

2. KRET J., MoJŹISZEK J. 2007. Mineralogiczne wiązania cynku $w$ wielkopiecowych $i$ stalowniczych pyłach i szlamach, Hutnik-Wiadomości Hutnicze, nr 7, s. 364.

3. Krupka D., SitKo J., OCHAB B. ET AL. 2006. Development of zinc production at the Boleslaw Zinc Plant, The IV International Conference Zinc '2006, Plovdiv, Bułgaria, s. 197.

4. TAjChman Z., TORA B. 2004. Technologia przerobu odpadów z huty T. Sendzimira $i$ możliwości ich wykorzystania, VI Międzynarodowa Konferencja Naukowa - teoretyczne i praktyczne problemy zagospodarowania odpadów hutniczych, Kraków, s. 70.

5. KAZABAER L.A., Kozlov P.A. 2005. Development of zinc production at the Chelyabinsk Zinc Plant, LEAD-ZINC '2005. Proceedings of the International Symposium on Lead and Zinc Processing, Kyoto, Japonia. 